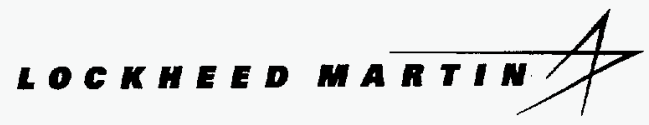

ENVIRONMENTAL

RESTORATION

PROGRAM

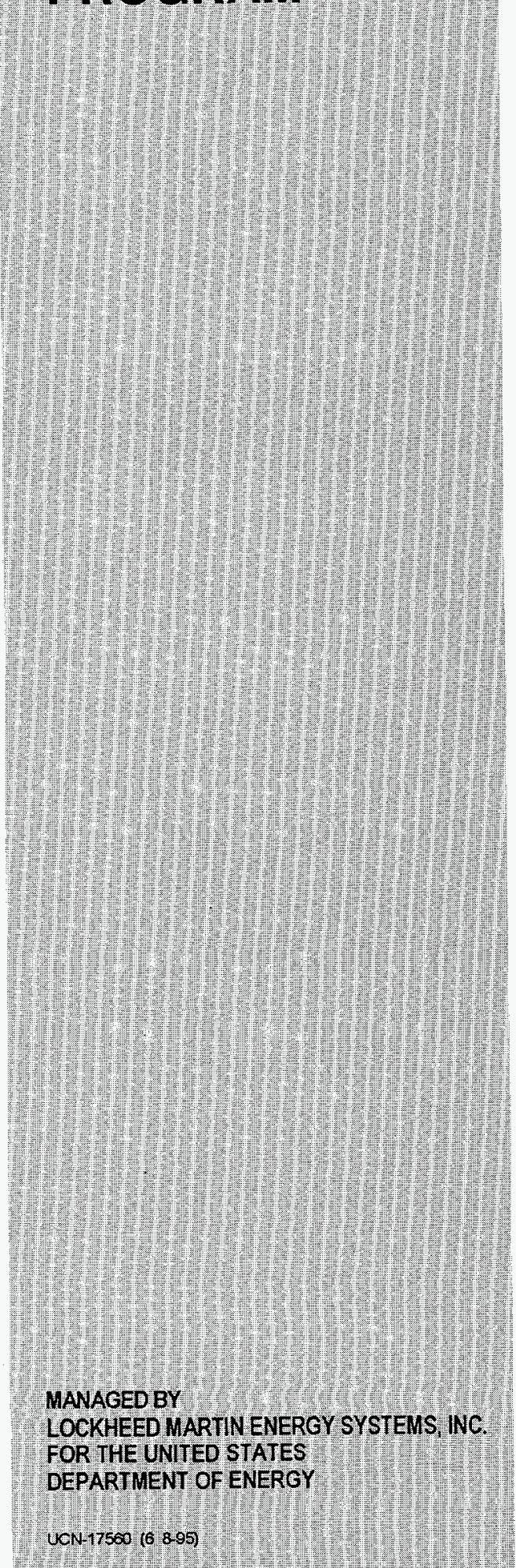

Best Management Practices and Work Plan for Installation of and Monitoring at Temporary Weirs and Flumes at NT-3, NT-4, and NT-5 Oak Ridge Y-12 Plant, Oak Ridge, Tennessee

\section{RECEIVED \\ EFD 241998 \\ OSTI}

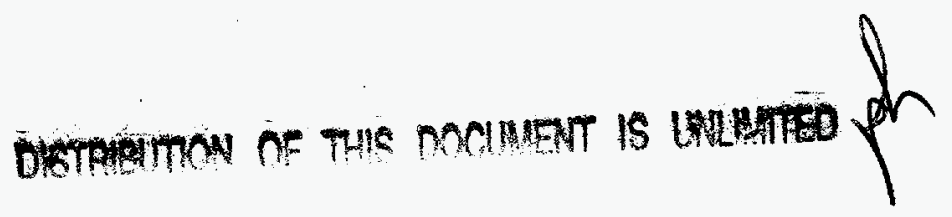
mon

This document has been approved by the Y-12 Plant Technical Information Office for release to the public. Date: $2 / 16 / 98$ 


\section{DISCLAIMER}

This report was prepared as an account of work sponsored by an agency of the United States Government. Neither the United States Government nor any agency thereof, nor any of their employees, makes any warranty, express or implied, or assumes any legal liability or responsibility for the accuracy, completeness, or usefulness of any information, apparatus, product, or process disclosed, or represents that its use would not infringe privately owned rights. Reference herein to any specific commercial product, process, or service by trade name, trademark, manufacturer, or otherwise does not necessarily constitute or imply its endorsement, recommendation, or favoring by the United States Government or any agency thereof. The views and opinions of authors expressed herein do not necessarily state or reflect those of the United States Government or any agency thereof. 


\section{DISCLAIMER}

Portions of this document may be illegible electronic image products. Images are produced from the best available original document. 


\title{
Best Management Practices and Work Plan for Installation of and Monitoring at Temporary Weirs and Flumes at NT-3, NT-4, and NT-5 Oak Ridge Y-12 Plant, Oak Ridge, Tennessee
}

Date Issued-February 1998

\author{
Prepared for the \\ U.S. Department of Energy \\ Office of Environmental Management \\ under budget and reporting code EW 20 \\ Environmental Management Activities at the \\ OAK RIDGE Y-12 PLANT \\ Oak Ridge, Tennessee 37831 \\ managed by \\ LOCKHEED MARTIN ENERGY SYSTEMS, INC. \\ for the \\ U.S. DEPARTMENT OF ENERGY \\ under contract DE-AC05-84OR21400
}




\section{BEST MANAGEMENT PRACTICES AND WORK PLAN \\ FOR INSTALLATION OF AND MONITORING \\ AT TEMPORARY WEIRS AND FLUMES AT NT-3, NT-4, AND NT-5 \\ APPROVALS}

C.w. Hecter

C. W. Hutzler, Waste Program Planning

$2 / 2 / 98$

Date

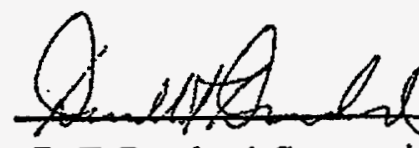

D. T. Drouhard, Systematic Management Services

$\frac{2-3-88}{2 a+e}$
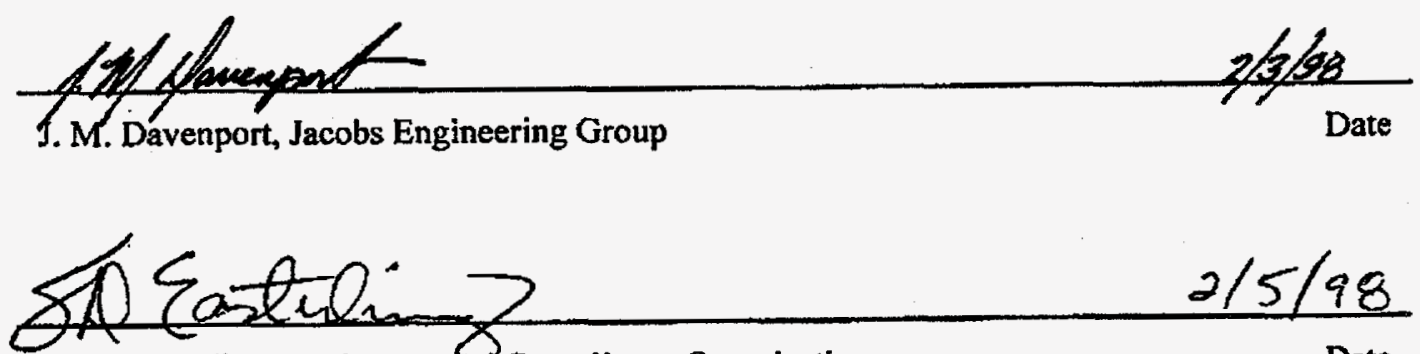

$2 / 5 / 98$

S. D. Easterling, Environmental Compliance Organization

Date

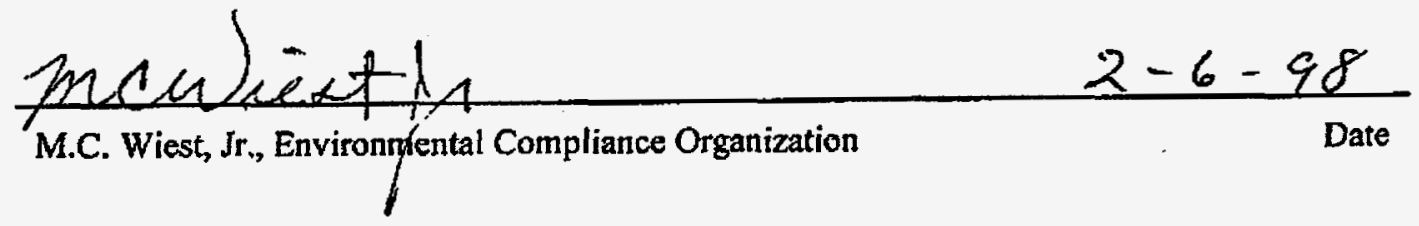




\section{CONTENTS}

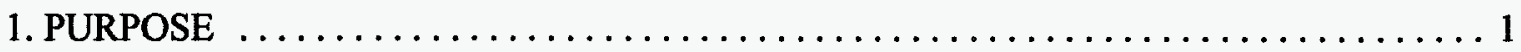

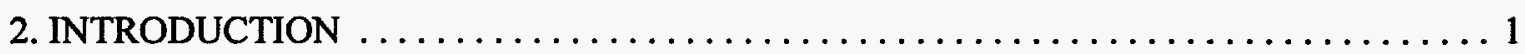

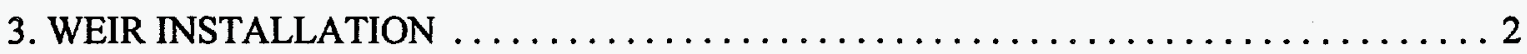

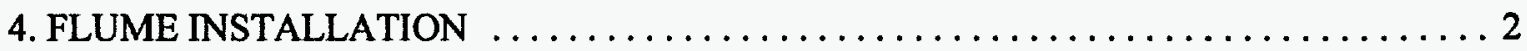

5. WEIR AND FLUME MAINTENANCE AND SILT REMOVAL $\ldots \ldots \ldots \ldots \ldots \ldots \ldots 2$

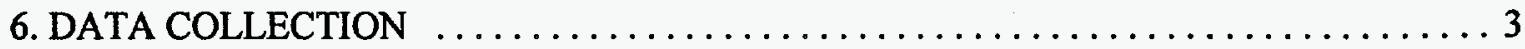

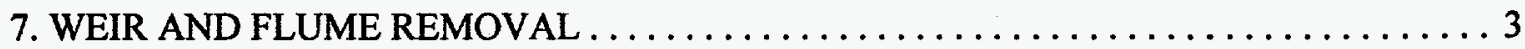

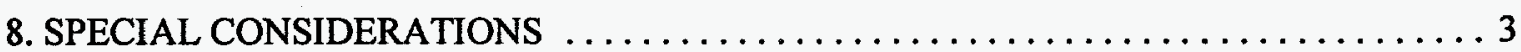

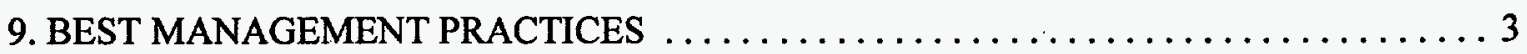

ATTACHMENT A: MAP OF INITIAL WEIR LOCATIONS ON NT-4 . . . . . . A A-1 ATTACHMENT B: MAP OF MONITORING LOCATIONS AT NT-3, NT-4, AND NT-5 . . B-1 


\section{PURPOSE}

This Best Management Practices (BMP) and Work Plan has been developed in order to maintain compliance with applicable regulatory requirements by documenting the practices that are required during the installation and maintenance of temporary weirs and flumes at the NT-3, NT-4, and NT- 5 tributaries, subsequent collection of water discharge data, and removal of the weirs and flumes. The practices included in this BMP comply with the Clean Water Act and the intent of Sect. 70-8-104(b) of the Tennessee Code Annotated: Tennessee Wildlife Resources Commission Proclamation 94-16 to prevent the destruction of the habitat of state-listed wildlife species that are designated as "in need of management."

\section{INTRODUCTION}

The purpose of the installation of temporary weirs and flumes at NT-3, NT-4, and NT-5 is to collect empirical surface water discharge data for the tributaries during baseflow conditions and following rainfall events, during 1997 and 1998 in support of Department of Energy (DOE) Oak Ridge Reservation Waste Management Alternatives Evaluation project studies.

In June of 1997, four temporary weirs were installed along the length of NT-4 in the locations indicated on Attachment A. A fifth monitoring station was also installed on NT-4 in the culvert south of the Haul Road. The design specifications and locations for the weirs were provided by the DOE prime contractor for the Oak Ridge Reservation Waste Management Alternatives Evaluation project. The weirs were fabricated by the Y-12 labor forces of Lockheed Martin Energy Systems (LMES) and installed under direction of the Y-12 Environmental Compliance Organization (ECO).

Three of these weirs and their associated dataloggers will be removed from NT-4 under oversight of ECO. Sampling points at the uppermost weir on NT-4 and at the metal culvert that passes under Haul Road will be continued. The other data loggers will be relocated to new sampling locations on flumes or weirs on NT-3, NT-4, and NT-5. A sampling point will be established on NT-3 and NT-5, respectively, at an upstream location. Additional sampling points will be established near the intersection of each tributary (i.e., NT-3, NT-4, and NT-5) with Bear Creek where the respective tributaries cross the Nolichucky Shale/Maynardville Limestone geological contact. Locations for the new sampling points are indicated on the map provided as Attachment B. All weir relocation and flume installation activities shall comply with the practices cited in this BMP.

ECO will perform weir and flume installation and removal. In addition, ECO will perform weir and flume inspection and maintenance upon request. Flow meters that collect data at ten minute intervals will be installed on each weir or flume and visual measurements using staff gauges mounted on each weir will also be performed. Data collection will be performed by ECO or a DOE contractor. In general, ECO will support the DOE contractor on an as-needed basis. 


\section{WEIR INSTALLATION}

A sledge hammer will be used to install the weirs by driving each weir into the stream bank and bottom perpendicular to stream flow. A level will be used ensure that the weirs are plumb before discharge measurements are made. Field measurements will be taken to ensure that each weir is plumb. Two rebar bracings will be driven to an approximate depth of $2 \mathrm{ft}$ into the stream bed on the downstream side of the weir when practical. Weir installation sites will be selected to ensure the designated storm-water control points specified in the Y-12 National Pollutant Discharge Elimination System (NPDES) Permit(s) are avoided by $50-100 \mathrm{ft}$.

\section{FLUME INSTALLATION}

Flume installation will be performed under the direction and oversight of ECO at Y-12. A level will be used ensure that the flumes are plumb before discharge measurements are made. Dataloggers will also be installed at each flume site. Minimal excavation is required during flume installation; hand tools such as trowels may be used as necessary. The lower (or most southerly) sampling point on NT-3 is located within a underground radiological contamination area. Installation and removal of the flume at this location will require oversight and field support from the Radiological Control Organization (RCO). This support is anticipated to include field monitoring and Radiological Work Permits. All workers involved in flume installation or removal at this location will be required to meet the specifications of the RWP including but not limited to Radiological Worker II training, dosimetry, and use of personal protective equipment. After installation of the flume, it is anticipated that $\mathrm{RCO}$ will reduce the requirements for routine access to the area for collection of monitoring data, as no soil disturbance will be required for these activities.

\section{WEIR AND FLUME MAINTENANCE AND SILT REMOVAL}

Inspection of the weirs and flumes will be conducted by ECO or the DOE contractor each time measurements are collected (i.e., every other week) and after storm events. If necessary, the weir will be re-leveled prior to collecting measurements.

In addition, as a part of pre-measurement inspections, ECO or the DOE contractor will check for accumulation of silt on the upstream side of each weir or flume. Any significant accumulation of silt will be removed after measurements are made, unless the silting interferes with data collection. Silt should be removed by shoveling it into a portable container that can be emptied some distance (e.g., $50 \mathrm{ft}$ ) from the stream so that silt can not reenter the stream. Under no circumstance should the silt be poured directly into the stream.

In the event that a flume must be substituted for a weir, the LMES Project Manager will coordinate this action and any approvals required by LMES, ECO, and the DOE prime contractor. This BMP Plan will be revised as necessary if any subsequent or additional requirements or instructions are required. 


\section{DATA COLLECTION}

Discharge measurements will be collected at a frequency determined by the DOE contractor(s), and recorded to the nearest $0.01 \mathrm{ft}$, using the staff gauge mounted on each weir and by download from the weir and flume flow meters. Data reports will consist of computer files and photocopies of field book entries and will include measurement, inspection, and maintenance activities as specified by the DOE prime contractor.

\section{WEIR AND FLUME REMOVAL}

At the end of the project, each of the weirs and flumes will be removed unless they are needed for other sampling activities and will be retained by ECO. Any silt accumulation shall be removed prior to disturbing the weirs and flumes, and the silt shall be relocated as described above in Sect. 5 and below in Sect. 9. Data loggers may be removed prior to the completion of the project due to the need for the equipment in other ECO operations. Removal will not occur prior to February 28, 1998 except in an emergency.

\section{SPECIAL CONSIDERATIONS}

The project recognizes that collection of flow data during the months of April through June requires special consideration from an environmental perspective as this season typically falls within the spawning period for the Tennessee dace, which is designated as an aquatic species of concern in need of management in the state of Tennessee. However, the collection of this data at this location during the wet season is imperative; in addition, the schedule and associated milestones associated with DOE project requiring the collection of surface water discharge data at these sites could be impacted if this data cannot be collected until the next seasonal opportunity. Any potential impact on the Tennessee dace will be minimized by complying with the requirements identified in this BMP during all field activities.

\section{BEST MANAGEMENT PRACTICES}

The following BMPs shall be followed during all activities. The Y-12 ECO shall be contacted at 574-3390 prior to deviating from these practices.

- Designated storm-water control points specified in the Y-12 National Pollutant Discharge Elimination System (NPDES) Permit(s) will be avoided by $50-100 \mathrm{ft}$.

- Every effort shall be made to minimize the potential for siltation during weir and flume installation and all other field activities. In the event that loose soil or sediment is generated or bare areas are created, the areas will be seeded and strawed. 
- Weir and flume inspections shall be conducted every other week and after storm events as a routine part of data collection activities. Inspections shall include observation for accumulation of silt on the upstream side of the weirs and flumes.

- Accumulation of silt should be removed after measurements are made, unless the silting interferes with data collection, by shoveling the silt into a portable container that can be emptied some distance (e.g., $50 \mathrm{ft}$ ) from the stream. Under no circumstance should the silt be poured directly into the stream.

- Information to be recorded in the field logbook shall include date, time, monitoring event (i.e., weekly or post-storm), location, measurement data, field conditions and inspection observations, maintenance activities (e.g., silt removal), and other pertinent observations.

- In the event that a spill or leak is observed or any adverse condition to surface waters or aquatic life occurs, the Y-12 Plant Shift Superintendent will be immediately contacted at 574-7172. 


\section{ATTACHMENT A:}

MAP OF INITIAL WEIR LOCATIONS ON NT-4 



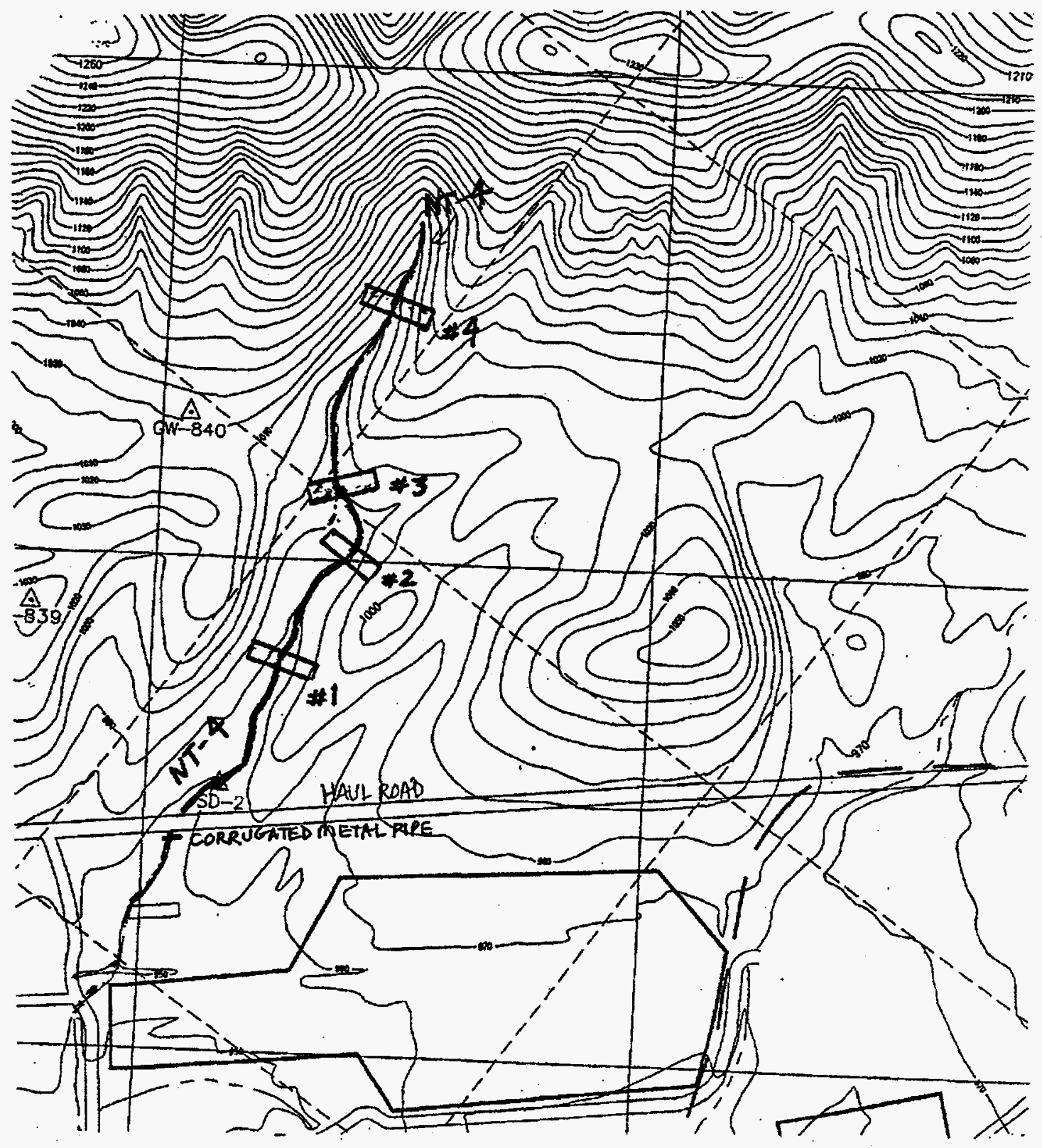

Fig. A.1. Locations of temporary weirs NT-4. 
ATTACHMENT B:

MAP OF MONITORING LOCATIONS

AT NT-3, NT-4, AND NT-5 
$i$ 
B-3

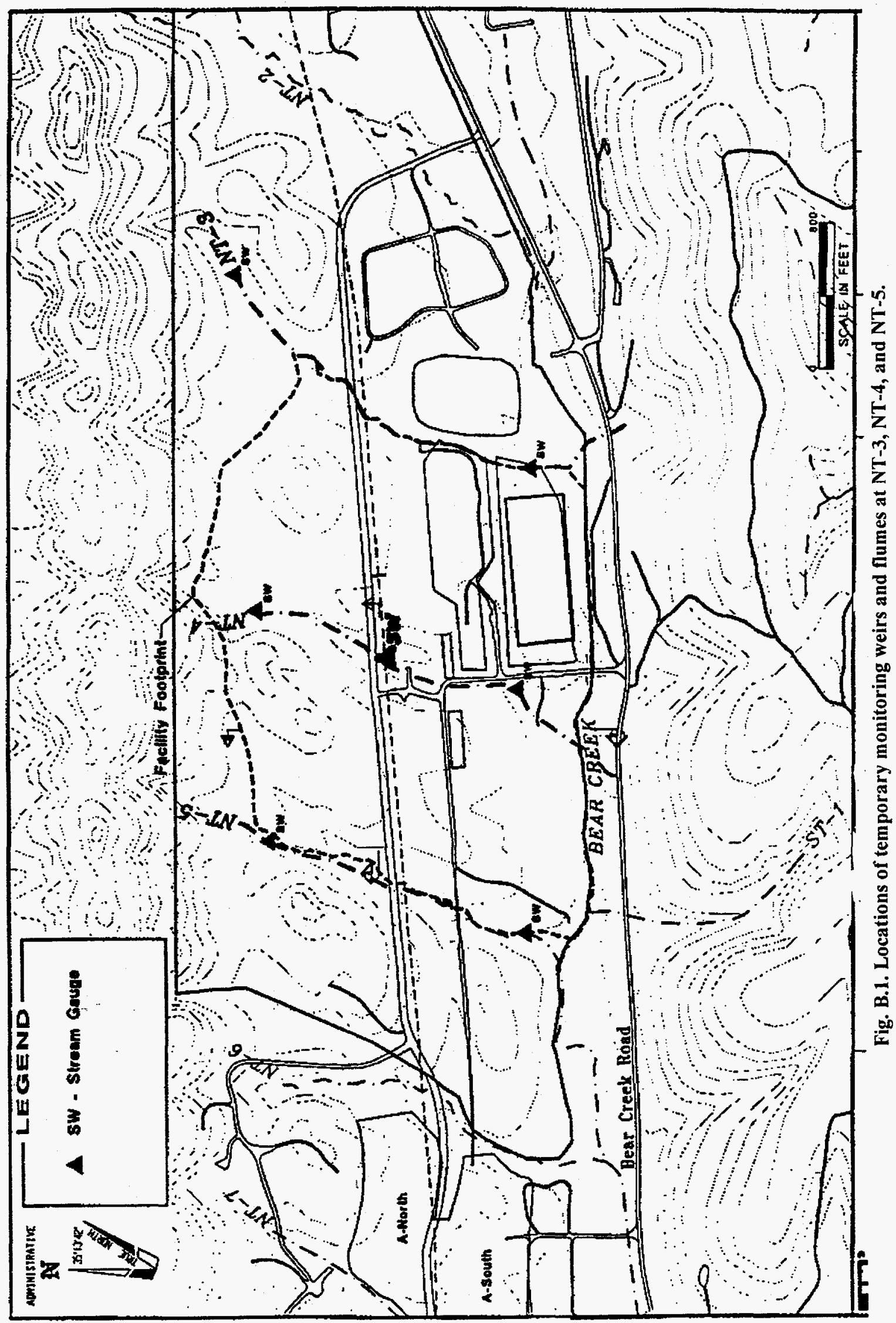


Y/ER/MS-11, Rev. 1

\section{DISTRIBUTION}

1. D. E. Bohrman

2. S. D. Easterling

3. M.S. Elliott

4. C. W. Hutzler

5. L. W. Manis

6. L. W. McMahon

7. H. C. Newsom

8. P. T. Owen

9. L. B. Raulston

10. L. O. Vaughn

11. M. C. Wiest, Jr.

12. File-EMEF DMC-RC

13. J. M. Davenport, Jacobs Engineering Group, 125 Broadway Avenue, Oak Ridge, TN 37830

14. D.T. Drouhard, SMS, 117 Broadway Avenue, Oak Ridge, TN 37830

15. G. D. Weiss, Jacobs Engineering Group, 125 Broadway Avenue, Oak Ridge, TN 37830 